\title{
Diet selection by young deer grazing mixed ryegrass/white clover pastures
}

\author{
Anneke Bootsma, Abu M. Ataja \\ and J. Hodgson \\ Departments of Agronomy and Animal Science, \\ Massey University, Palmerston North
}

\begin{abstract}
Groups of weaned red deer stags were grazed from May to December 1988 under continuous stocking management to maintain mixed perennial ryegrass/white clover pastures, with or without directdrilled 'Grasslands Moata' annual ryegrass, at sward heights of $5 \mathrm{~cm}$ and $10 \mathrm{~cm}$. Diet selection was estimated from (a) samples of fresh ingesta collected from rumen tistulated animals, and (b) defoliation of marked populations of grass tillers and clover stolon units. Proportion of clover in ingesta samples was consistently smaller than in the pasture, whereas plant observations showed similar frequency and severity of defoliation of grass and clover except in December, when clover was defoliated more severely. Observations on pasture structure indicated that clover foliage occurred lower in the canopy, and was grazed closer to the soil level, than grass leaves. Therefore, despite the evidence on diet composition, the results are interpreted as indicative of active selection for clover by the deer. The results are compared with published evidence on diet selection by grazing sheep.
\end{abstract}

Keywords diet selection, deer, ryegrass, white clover, defoliation frequency, defoliation severity

\section{INTRODUCTION}

Farmed red deer are now an important part of the rural economy in New Zealand, but little is known about their dietary preferences under controlled grazing management or their impact on the composition of mixed pastures, Hunt \& Hay ( 1989) reported the results of studies on the preferences of deer offered access to a range of plants in singlespecies plots. This paper reports the results of a preliminary investigation of diet selection by weaned stags grazing mixed grass/legume pastures.

\section{METHODS}

Weaned red deer stags were grazed from May to December 1988 on long-established pastures of perennial ryegrass (Lolium perenne)/white clover (Trifolium repens), with or without annual ryegrass (Lolium multiflorum) cv. 'Grasslands Moata' introduced by direct drilling 13 weeks before the study began. Each pasture type was maintained close to rising plate meter heights of $5 \mathrm{~cm}$ and $10 \mathrm{~cm}$ by adjusting animal numbers under continuous stocking management. There were four 1 ha paddocks in a $2 \times 2$ factorial design without replication. Details of pasture preparation and management are given in Ataja et al. (1989).

Pasture height was measured with the plate meter twice weekly and used as a basis for stock adjustments.

Dietary selection was estimated in two ways:

(a) In June and November, samples of newly ingested herbage were taken from the rumens of 2-4 fistulated yearling stags grazing each plot (Theurer 1970) and the relative proportions of constituent plant species were estimated using a flotation technique (D.A. Clark, pers. comm.). Comparisons were made with estimates of pasture composition from hand separations of 5 samples of herbage cut to ground level in each plot. Observations were made on all plots in June, and on $5 \mathrm{~cm}$ pastures in November.

(b) In October, November and December the frequency and severity of defoliation of populations of 20 marked tillers of $L$. perenne and $L$. multiflorum, and 20 stolons of $T$. repens per paddock were recorded. Ten $2 \mathrm{~m}$ transects containing marked units of each species were positioned at random within each pasture, and records of growth and defoliation were derived from repeated observations on leaf number and size (length for grasses; area (Williams et al. 1964) for T. repens) made at 3 to 4 day intervals (Bircham \& Hodgson 1983) for 8, 9 and 18 days respectively in October, November and December. Observations were confined to $10 \mathrm{~cm}$ pastures in October, and 5 $\mathrm{cm}$ pastures in November and December. The vertical distribution of plant tissue within the sward canopy was also measured using an inclined point quadrat (Grant 1981) set at 32.5" to the horizontal and recording a minimum of 200 contacts per pasture. The heights of leaves of marked plant units (i.e. the vertical distance from soil level to the tip of the uppermost leaf) were measured before and after grazing.

\section{RESULTS AND DISCUSSION}

Pasture heights were maintained close to target until October, but subsequently increased to $2-3 \mathrm{~cm}$ above target in December. 


\section{B otanical composition of ingesta and pasture}

Separate identification of $L$. perenne and $L$. multiflorum in ingesta samples was difficult, so the results (Table 1) are based on a simple comparison between grass and clover proportions. The weed component of all pastures was negligible. White clover made up a smaller proportion of the diet than that of the pasture in all comparisons, though differences were proportionately larger in November than in June.

\section{Plant observations}

Observations were confined to marked plant units of $L$. perenne, L. multiflorum and $T$. repens. Frequency and severity of defoliation of populations of marked units for each species are defined and

Table 1 Comparison of the relative proportions of gras and clover in pasture $(\% \mathrm{DM})$ and in the diet of grazing deer (\% leaf area)

\begin{tabular}{|c|c|c|c|}
\hline \multicolumn{2}{|c|}{$\begin{array}{l}\text { Perenn. ryegrass/ } \\
\text { white clover }\end{array}$} & \multicolumn{2}{|c|}{$\begin{array}{l}\text { Perenn./annual } \\
\text { ryegrass/white clover }\end{array}$} \\
\hline Grass $\S$ & Clover & Grass $\S$ & Clover \\
\hline
\end{tabular}

J une (means of $5 \mathrm{~cm}$ and $10 \mathrm{~cm}$ pastures)

Pasture composition

$\begin{array}{lrllll}\text { (\%DM) } & 95.210 .95 & 4.8 \pm 0.95 & 92.2 \mathrm{f} 2.7 & 7.8 \pm 2.7\end{array}$

Diet composition

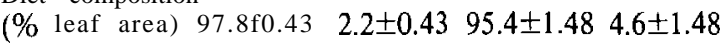

November $(5 \mathrm{~cm}$ pastures)

Pasture composition

(\%Dm) $\quad 85.8 \pm 1.4114 .2$ f $1.4 \quad 83.8 \pm 1.616 .2 \pm 1.6$ Diet composition

$\begin{array}{lllll}(\% \text { leaf area) } & 96.7 \pm 0.88 & 3.3 \mathrm{f} 0.88 & 93.4 \pm 2.06 & 6.6 \pm 2.06\end{array}$

$\S$ All grasses presented in Table 2. Severity of defoliation, a compound effect of the frequency and the proportion of leaf removed from a unit at each defoliation, provides a measure of the relative grazing pressure imposed on each species. Grazing severity is related to linear and area estimates respectively for grasses and clover, but this is not considered to introduce any substantial bias into comparisons between species except to the extent that it ignores the contribution of clover petiole.

Statistical evaluation of the data was based on analysis of variance of transect mean values for each species. The short recording periods in October and November contributed to variability in estimates of defoliation frequency, but trends were consistent over periods.

The frequency of defoliation of white clover was lower than that of perennial ryegrass, or of the mean of the two grasses, in October and November, but higher in December. Results for severity of defoliation followed a similar pattern. Few of the differences were significant, but they were consistent between pasture types. Comparative data for $L$. perenne and $L$. multiflorum were inconsistent. The values for L. perenne in the overdrilled pasture in October appear to be aberrant.

The animal data might be taken to indicate selective avoidance of clover by deer, and the pasture measurements suggest at least neutrality in response. However, these interpretations fail to take into account between-species differences in distribution of foliage within the pasture canopy, and their impact on grazing behaviour.

Leaf height (the vertical distance from ground level to the tip of the tallest leaf) was greater for grasses than for clover both before and after grazing at the December measurement (Table 3). Results

Table 2 Comparison of the frequency (\% of each population of marked units grazed per day) and severity (\% of leaf removed from marked population per day) of defoliation of grass and clover components of pastures grazed by young stags.

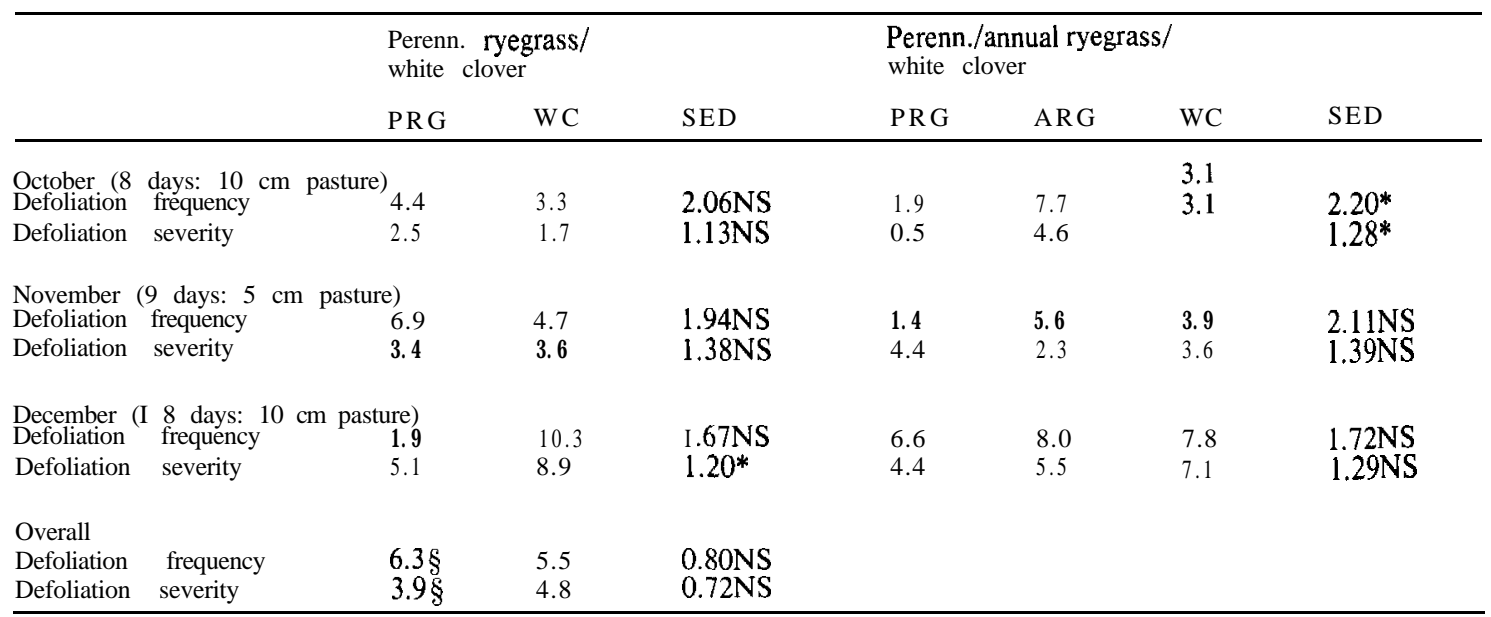

\&. perenne and L. multiflorum combined

Significant at $\mathrm{P}<0.05$ 
for earlier periods were similar. Overall, leaf heights for grasses (L. perenne and L. multiflorum combined) and clover were 82 vs $46 \mathrm{~mm}$ (SED $3.07^{* *}$ ) before grazing and 69 vs $41 \mathrm{~mm}$ (SED $\left.1.33^{* *}\right)$ after grazing.

Analysis of the point quadrat data indicated that, overall, only $5 \%$ of clover contacts were recorded above $40 \mathrm{~mm}$ from ground level. Corresponding values for L.perenne and L. multiflorum were $26 \%$ and $30 \%$ respectively. The relative proportions of live grass and clover above $40 \mathrm{~mm}$ from ground level (corresponding approximately to mean grazed height for the clover) in November were $87.2 \%$ and $12.8 \%$ respectively for the old pasture, and $91.2 \%$ and $8.8 \%$ for the direct-drilled pasture. When compared with the equivalent dietary proportions in Table 1 these values still suggest preferential selection of grass by the deer. However, the differences between the composition of the diet and of grazed strata were smaller than the differences between diet and whole sward (see also Milne et al. 1982).

Table 3 Height of marked units of grass and clover (measured from ground level to the uppermost leaf tip) before and after grazing in December.

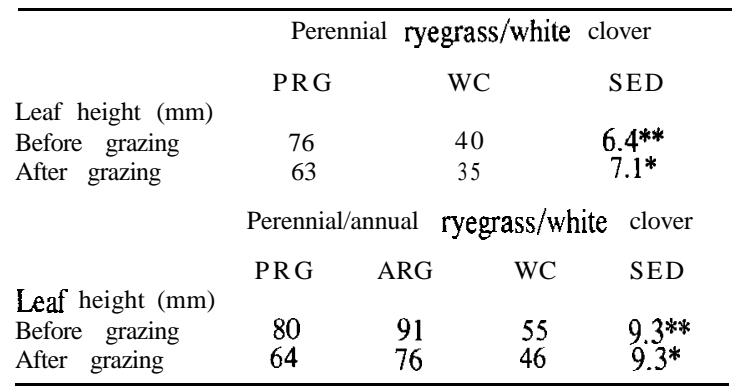

There is no obvious reason why the animal measurements should indicate a greater degree of discrimination against clover than did the pasture measurements, and further technique evaluation may be needed to resolve the issue. Preliminary assessment of the flotation technique demonstrated good prediction of real DM proportions of grass and clover in mixed samples (J. Hodgson and D.A. Clark, unpub. data).

The results of the pasture studies indicate that, in proportionate terms, clover was subjected to a severity of defoliation which was at least equal to that of the grasses, despite the fact that clover foliage was carried lower in the sward canopy. The implication is that the deer were discriminating actively in favour of the clover. Furthermore, the generally lower defoliation height for clover than for grass provides a ready explanation for the lower disposition of clover foliage within the canopy.

Hunt \& Hay ( 1989) also observed preference for legumes over grasses where deer were offered access to small plots of single plant species in free- choice trials. However, in order to demonstrate discrimination unequivocally in mixed pastures, more information would be required on the degree of aggregation of grass and clover within the pasture (Clark \& Harris 1985), and the vertical distribution of grass leaf lamina and stem relative to clover lamina and petiole. Differences in leaf distribution between $L$. perenne and $L$. multiflorum were relatively small (Table 3) and, if the aberrant values for L. perenne in Table 2 are discounted, there was little indication of consistent discrimination between them.

There is little strictly comparable evidence for other little animal species. Milne et al. (1982) showed that the apparent preference for clover exhibited by sheep grazing mixed $L$. perenne/T. repens pastures was explained by a higher proportion of clover foliage in the upper strata than in the sward as a whole. Milne's swards were set up under cutting managements and so were not subject to preliminary grazing effects. Bircham \& Hodgson (1983) observed a concentration of $T$. repens leaf in the upper horizons of ryegrass/clover pastures grazed by sheep under continuous stocking management, which was related to greater proportionate defoliation of $T$. repens than L. perenne and L'Huillier et al. (1984) also showed that the distribution of green leaf within the sward canopy influenced selective grazing by sheep. However, diet selection from mixed swards is not always determined by the distribution of grass and clover foliage within them (Clark et al. 1986). Clark et al. (1984) and Curll \& Wilkins (1982) observed similar frequencies of defoliation for marked units of L. perenne and $T$. repens in pastures grazed by sheep, but pasture structure was not defined in these studies.

\section{CONCLUSIONS}

It is inferred that in this study the deer exerted greater selection pressure for white clover than for the ryegrass component of mixed swards, and that this differential affected pasture structure. The available evidence suggests that in comparable circumstances sheep would be less selective for clover than the deer, but more information is needed for a range of pasture conditions and animal classes before this can be accepted as a generalisation.

\section{REFERENCES}

Ataja, A.M.; Wilson, P.R.; Purchas, R.W.; Hodgson, J.; Barry, T.N.; Hay, R.J.M. 1989. A study of early venison production from grazing Red Deer. Proceedings NZ Animal Production Society (In press)

Bircham, J.S.; Hodgson, J. 1983. The influence of sward conditions on rates of herbage growth in senescence in mixed swards under continuous stocking management. Grass and Forage Science 39: 111-115. 
Clark, D.A.; Chapman, D.F.; Land, C.A. 1984. Defoliation of Lolium prenne and Agrostis spp. tillers and Trifolium repens stolons in set stocked and rotationally grazed hill pastures. NZ Journal of Agricultural Research 27: 289-301.

Clark, D.A.; Harris, P.S. 1985. Composition of the diet of sheep grazing swards of differing white clover content and spatial distribution. NZ Journal of Agricultural Research 28 233-240.

Clark, D.A.; Hodgson, J.; Robertson, E.; Barthram, G.M. 1986. Diet selection by sheep and cattle from mixed grass clover swards. Hill Farming Research O rganisation Biennial Report 1984-85.

Curll, M.L.; Wilkins, R.J. 1982. Frequency and severity of defoliation of grass and clover by sheep at differen stocking rates. G rass and Forage Science 37: 291-297.

Grant, S.A. 1981. Sward components. In Hodgson J. et al. (Eds.) Sward Measurement Handbook. British Grassland Society, Hurley. pp 71-92.

Hunt, W.F.; Hay, R.J.M. 1989. Alternative pasture species for deer production in the Waikato. Proceedings of the Ruakura Deer Industry Conference. MAFTech, Hamilton, pp. 31-33.
LHuillier, P.J.; Poppi, D.P.; Fraser, T.J. 1984. Influence of green leaf distribution on diet selection by sheep and the implications to animal performance. Proceedings $N Z$ Animal Production Society 44: 105-107.

Milne, J.A.; Hodgson, J.; Thompson, R.; Souter, W.G.; Barthram, G.T. 1982. The diet ingested by sheep grazing swards differing in white clover and perennial ryegrass content. Grass and Forage Science 37: 209-218.

Theurer, C.B. 1970. Determination of botanical and chemical composition of the grazing animal's diet. Proceedings of a National Conference in Forage Quality Evaluation and Utilisation. University of Nebraska 1969, Section J. pp. I-17.

Williams, R.F.; Evans, L.T.; Ludwig, J.L. 1964. Estimation of leaf area for clover and luceme. Australian Journal of Agricultural Research 15: 231-233. 